GRASAS Y ACEITES 67 (4)

October-December 2016, e158

ISSN-L: 0017-3495

doi: http://dx.doi.org/10.3989/gya.0449161

\title{
Extra-virgin olive oil and its phenolic extract prevent inflammatory response and joint damage in murine experimental arthritis*
}

\author{
M.A. Rosillo ${ }^{\mathrm{a}}$, M. Sánchez-Hidalgo ${ }^{\mathrm{a}}$ and C. Alarcón-de-la-Lastra ${ }^{\mathrm{a}, 凶}$ \\ ${ }^{\text {a } D e p a r t m e n t ~ o f ~ P h a r m a c o l o g y, ~ F a c u l t y ~ o f ~ P h a r m a c y, ~ U n i v e r s i t y ~ o f ~ S e v i l l e, ~ S p a i n . ~}$ \\ Corresponding author: calarcon@us.es
}

Submitted: 18 April 2016; Accepted: 27 June 2016

SUMMARY: The consumption of EVOO in Mediterranean countries has shown beneficial effects. A wide range of evidence indicates that the phenolic compounds present in EVOO are endowed with anti-inflammatory properties. In this work, we evaluated the effects of dietary EVOO and treatment with its phenolic extract (PE) in a model of RA, the collagen-induced arthritis (CIA) in mice. On day 0 , DBA-1/J mice were immunized with bovine collagen type II (CII). On day 21, the mice received a booster injection. We have demonstrated that EVOO and its PE decreases joint edema, cell migration, cartilage degradation and bone erosion. Our data indicate that dietary EVOO and PE treatment inhibit JNK, p38 and signal transducer and STAT-3. In addition, both EVOO and PE decrease NF- $\mathrm{KB}$ translocation leading to the down-regulation of the arthritic process. These results support the interest of natural diet components in the development of therapeutic products for arthritic conditions.

\section{KEYWORDS: CIA; EVOO; Inflammatory response; Olive oil; Polyphenols; Rheumatoid arthritis}

RESUMEN: El aceite de oliva extra virgen y su fracción polifenólica previenen la respuesta inflamatoria y el daño articular en un modelo de artritis experimental en murino. El consumo de Aceite de oliva virgen extra (AOVE) en los países mediterráneos ha demostrado tener efectos beneficiosos. Una amplia gama de pruebas indica que los compuestos fenólicos presentes en el AOVE tienen propiedades anti-inflamatorias. En este trabajo, se evaluaron los efectos de AOVE y el tratamiento en dieta de su fracción polifenólica (FP) en un modelo de la artritis reumatoide inducida por colágeno (CIA) en ratones. En el día 0, los ratones DBA-1/J se inmunizaron con colágeno bovino tipo II (CII). En el día 21, los ratones recibieron una inyección de refuerzo. Hemos demostrado que el AOVE y su FP disminuyen conjuntamente el edema, la migración celular, la degradación del cartílago y erosión ósea. Nuestros datos indican que la dieta con AOVE y el tratamiento con FP inhiben JNK, p38 y el transductor de señal y activador de la transcripción 3 (STAT-3). Además, tanto el AOVE como la FP disminuyen la translo-

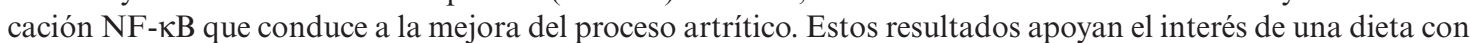
componentes naturales y el desarrollo de productos terapéuticos para desordenes artríticos.

PALABRAS CLAVE: Aceite de oliva; Artritis reumatoide; CIA; EVOO; Polifenoles; Respuesta inflamatoria

Citation/Cómo citar este artículo: Rosillo MA, Sánchez-Hidalgo M, Alarcón-de-la-Lastra C. 2016. Extra-virgin olive oil and its phenolic extract prevent inflammatory response and joint damage in murine experimental arthritis. Grasas Aceites 67, e158. doi: http://dx.doi.org/10.3989/gya.0449161.

Copyright: (C) 2016 CSIC. This is an open-access article distributed under the terms of the Creative Commons Attribution (CC-by) Spain 3.0 License.

*This manuscript was presented in the I Workshop INSA-UB "The Universe of the Olive Oil", in November 2015. 


\section{INTRODUCTION}

Rheumatoid arthritis (RA) is a chronic systemic inflammatory disease characterized by inflammation of the synovial membrane and progressive destruction of the articular cartilage and bone. (Salgado and Maneiro, 2014).

RA patients exhibit a chronic inflammatory condition which usually affects symmetrically arthrodial and small joints of the hands and feet.

Global prevalence of RA has been estimated to be around $0.5-1.0 \%$ of adults in developed countries with a large variation across regions and approximately three times more common in the female gender. The disease may begin at any age, but around $80 \%$ of all patients initiate the disease between the ages of 35 and 50 (Rudan et al., 2015).

Although the specific triggers and exact mechanisms of tissue damage in RA are still unknown, an increase in inflammatory mediators as well as a deregulation of the immune system with uncontrolled $\mathrm{T}$ cell activity play a remarkable role in its pathogenesis. Pharmacological treatment in AR including non-steroidal anti-inflammatory drugs (NSAIDs), glucocorticoids, disease-modifying antirheumatic drugs (DMARDs) and biological agents have improved the signs and symptoms of RA, but these drugs are only effective in a fraction of patients and have other limitations including a high cost, the requirement for parenteral administration and drastic side effects. Therefore, new therapeutic strategies are under investigation including nutritional therapy. The beneficial effects of the Mediterranean diet have been proven not only in cardiovascular diseases but also in diabetes, obesity, arthritis and cancer (Cárdeno et al., 2013). Evidence points out that the Mediterranean diet decreases both pain and disease activity leading to better outcomes, and a decrease in the doses of anti-inflammatory drugs which cause considerable side effects (Smedslund et al., 2010).

Olive oil is the most commonly used culinary fat in the Mediterranean area and is described as a key bio-active food (Puertollano et al., 2010). Extra virgin olive oil (EVOO) is obtained from the fruit of the olive tree (Olea europea L.) solely by mechanical or other physical means under conditions that do not alter its natural composition.

Traditionally the beneficial effects of EVOO have been ascribed to oleic acid by influencing arachidonic acid metabolism (Bermúdez et al., 2011; Carrillo et al., 2012). However, a wide range of evidence indicates that many of the beneficial effects of EVOO intake are due to its minor highly bioactive components (about $1-2 \%$ of oil weight) (Alarcón de la Lastra et al., 2001). Among them, phenolic compounds such as hydroxytyrosol, tyrosol and oleuropein have shown anti-inflammatory and antioxidant effects (Omar, 2010). Current experimental studies support a beneficial role of the polyphenols from EVOO in several inflammatory diseases, including RA (Gong et al., 2009; Impellizzeri et al., 2011; Martinez-Dominguez et al., 2001). Although EVOO has demonstrated anti-inflammatory effects, little evidence has been reported regarding its possible immunomodulatory effects.

\section{MATERIALS AND METHODS}

\subsection{Animals, diets and treatments}

\subsubsection{Collagen-induced arthritis (CIA)}

Arthritis was induced in male DBA-1/J mice (Janvier, Le Genest St Isle, France) of 11 weeks of age. All studies were performed in accordance with European Union regulations for the handling and use of laboratory animals. The protocols were approved by the institutional Animal Care and Use Committee (University of Valencia, Spain). Bovine collagen type II (CII) $(2 \mathrm{mg} / \mathrm{mL}$ in dilute acetic acid; MD Biosciences, Zürich, Switzerland) was emulsified in equal volumes of Freund's complete adjuvant $(2 \mathrm{mg} / \mathrm{mL}$ Mycobacterium tuberculosis, strain H37Ra; Difco, Detroit, MI, USA). On day $0, \mathrm{DBA}-1 / \mathrm{J}$ mice were immunized at the base of the tail with $100 \mu \mathrm{g}$ of bovine CII. On day 21, the mice received an intra-peritoneal booster injection of $100 \mu \mathrm{g}$ of CII dissolved in a phosphatebuffered saline. The mice were considered to have arthritis when significant changes in redness and/ or swelling were noted in the digits or in other parts of the paws. Joint inflammation was scored visually in each paw, using a scale of $0-2$ where $0=$ uninflamed, $1=$ mild, $1.5=$ marked and $2=$ severe. Scoring was performed by two independent observers without any knowledge of the experimental groups.

\subsubsection{EVOO versus $S O$ diets}

Three-week-old male DBA-1/J mice were randomly placed into four experimental groups: (1) The Sham sunflower diet (SO-Sham) group received a diet elaborated with a marketable sunflower oil; (2) The CIA sunflower diet (SO-CIA) group received a diet elaborated with a marketable sunflower oil; (3) Sham EVOO diet (EVOO-Sham) group were fed with a diet made with a marketable EVOO characterized by a high content in polyphenolic compounds $(600 \mathrm{ppm})$ (Oleoestepa ${ }^{\circledR}$, Seville, Spain) and (4) The CIA EVOO diet (EVOO-CIA) group were fed with a diet made with a marketable EVOO characterized by a high content in polyphenolic compounds $(600 \mathrm{ppm})\left(\right.$ Oleoestepa ${ }^{\circledR}$, Seville, Spain). All diets were formulated on the basis of the American Institute of Nutrition (AIN) 
standard reference diet with the modification of various sources of carbohydrate, at $10 \%$ of oil and were prepared by mixing the respective compounds under yellow light and stored at $-80{ }^{\circ} \mathrm{C}$. Fresh diets were provided daily. The animals were fed with the corresponding diet for six weeks previous to the CIA induction and during the experiment time.

\subsubsection{PE treatment}

On day 29 after first immunization, the animals were randomly placed into control and treatment groups. The study was performed on four groups of mice $(\mathrm{n}=10)$ : Sham group (Sham), CIA group (CIA) and two treatment groups: CIA mice with phenolic extract (PE) treatment (PE 100 and 200 $\mathrm{mg} / \mathrm{kg}$, orally, once a day from days 29 to 41). PE was obtained according to the method described by Vazquez Roncero et al. (Vázquez-Roncero, 1976).

\subsection{Assessment of inflammatory mediators and mechanism}

On day 42 after immunization mice were anesthetized, blood samples were taken through an intra-cardiac puncture and the animals were killed by cervical dislocation. Their paws were amputated and processed for either histological analysis or homogenization and assessment of inflammatory mediators and mechanisms.

To perform histological analyses, knee joints were fixed in $4 \%$ formalin. After decalcification in $10 \%$ EDTA, the specimens were processed for paraffin embedding. Tissue sections $(7 \mu \mathrm{m})$ were stained with haematoxylin and eosin.

IL- $1 \beta$ and TNF- $\alpha$ levels were measured in the hind paw homogenates using ELISA kits.

Changes in protein expression were determined in hind paw homogenates by the western blot analysis. The antibodies used were: rabbit polyclonal anti-IкB- $\alpha$ (1:1000; Cell Signalling Technology, USA), rabbit polyclonal p65 (1:200, Santa Cruz Biotechnology, Inc.), rabbit polyclonal anti p-JNK and rabbit polyclonal anti-JNK (1:1000; Santa Cruz Biotechnology, Inc.), mouse polyclonal anti-p-p38 and rabbit polyclonal anti-p38 (1:1000; Santa Cruz Biotechnology, Inc.) and mouse polyclonal antip-STAT3 (1:200; Santa Cruz Biotechnology, Inc.).

\subsection{Data analysis}

All values in the figures and text are expressed as arithmetic means \pm S.E.M. Data were evaluated with Graph Pad Prism Version 5.04 software. Statistical significance was evaluated by two-way (time course) or one-way (rest of parameters) analysis of variance (ANOVA), followed by Bonferroni's test. P values $<.05$ were considered statistically significant.

\section{RESULTS AND DISCUSSION}

Our results revealed that EVOO, as the lipid component in the diet, and its PE effectively exhibited preventive and therapeutic effects, respectively, in the development of inflammatory arthritis and joint damage in CIA arthritic mice in comparison with those CIA mice fed with SO or the standard diet (Figure 1). This effect was correlated to an improved arthritis score, a minor inflammatory cell infiltration into articular tissues, reduced exudation into the synovial space, synovial hyperplasia and cartilage erosion (Figure 2). Over-expression of pro-inflammatory cytokines, such as IL-1 $\beta$ and TNF- $\alpha$ may activate osteoclasts and macrophages and recruit leukocytes in inflamed joints. It is wellknown that IL-17 is able to induce the release of IL-8 and IL-6, and plays a remarkable role in the additive/synergistic effects induced by TNF- $\alpha$ and IL-1 $\beta$ (Jeong et al., 2004). Our results indicate that animals fed an EVOO diet or treated with the PE showed a significant reduction in IL-1 $\beta$ and TNF- $\alpha$ proinflammatory cytokines levels in paw homogenates (Figure 3). Abnormal signaling pathways play an important role in the inflammatory process and can lead to a deregulation of the inflammatory response which is crucial in RA pathogenesis. Nuclear factor $\kappa \mathrm{B}(\mathrm{NF}-\kappa \mathrm{B})$ is a crucial transcriptional activator for the expression of multiple pro-inflammatory genes involved in the microenvironment of the arthritic joints, playing an important role in the development of RA. (Morel and Berenbaum, 2004; Okamoto et al., 2010). Our results suggested that dietary EVOO and PE treatment suppressed NF- $\mathrm{BB}$ activation in CIA-induced arthritic mice (Figure 4). Similarly, the mitogen-activated protein kinase (MAPK) family also plays critical roles in RA pathogenesis (Han et al., 2001; Suzuki et al., 2000) regulating cytokine production, and activating the janus kinase-signal transducer and activator of the transcription (JAK-STAT) signaling pathway through STAT-3 phosphorylation (Aaronson and Horvath, 2002). Our results demonstrated that a EVOO diet and PE treatment intake significantly reduced both MAPKs and STAT-3 activation (Figures 5 and 6).

Altogether, our results confirm, for the first time, that EVOO and its minor polyphenolic fraction intake dramatically attenuated the progression and severity of arthritis in CIA DBA/1 J mice through NF- $\kappa \mathrm{B}$, MAPKs and JAK-STAT signaling pathway inhibition, decreasing the inflammatory cascade induced by CIA.

\section{CONCLUSIONS}

Our results suggest that EVOO exerts preventive effects in the development of experimental RA, with its multiple minor components playing a key role in these healthy benefits. Thus, EVOO may be 
(A)
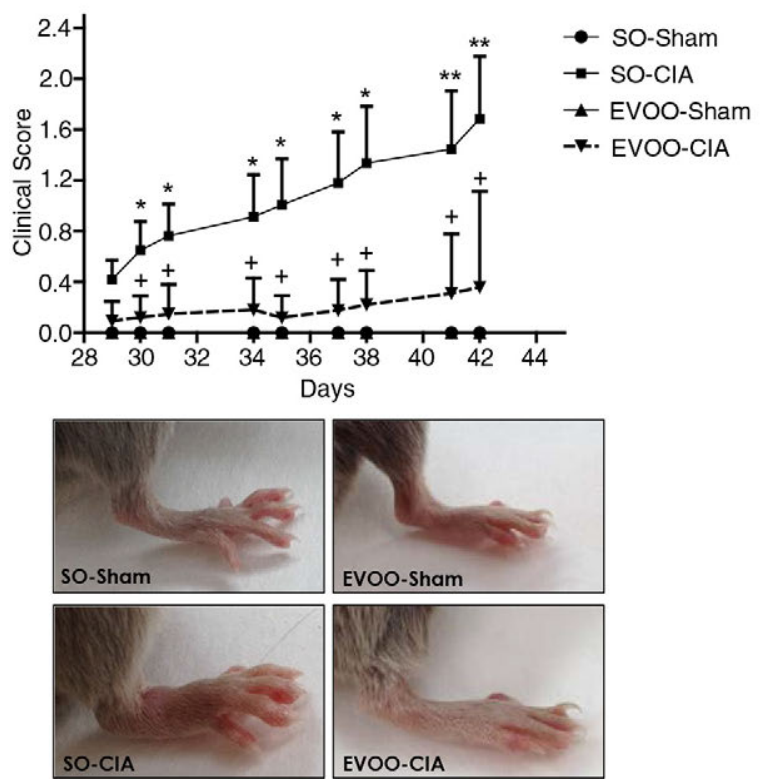

(B)
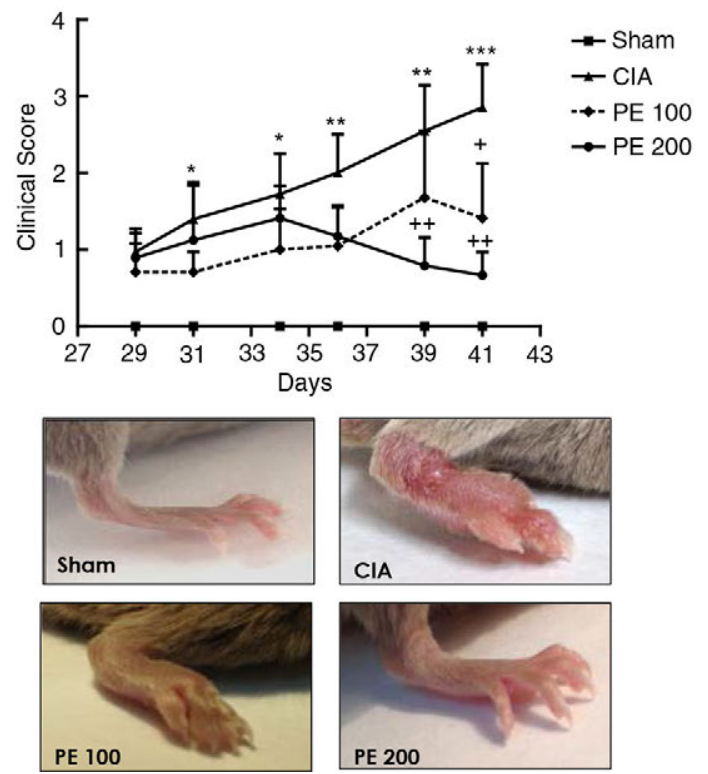

FIGURE 1. Time course of the arthritis macroscopic score and representative photographs of hind paws at the end of the experiment (day 42). (A) Dietary EVOO treatment: SO-Sham, non-arthritic mice fed with SO diet; EVOO-Sham, non-arthritic mice fed with EVOO diet; SO-CIA, control arthritic group fed with SO diet; EVOO-CIA, arthritic mice fed with EVOO diet. (B) PE treatment: Sham, non-arthritic mice; CIA, control arthritic group; PE 100, arthritic mice treated with PE (100 mg/kg/day p.o. from days 29 to 41 after immunization); PE 200, arthritic mice treated with PE (200mg/kg/day p.o. from days 29 to 41 after immunization. Data represent mean \pm S.E.M. $n=10$. ${ }^{*} p<0.05$ and ${ }^{* *} p<0.01$ vs. Sham; $+p<0.05$ and $++p<0.01$ vs. CIA.

(A)
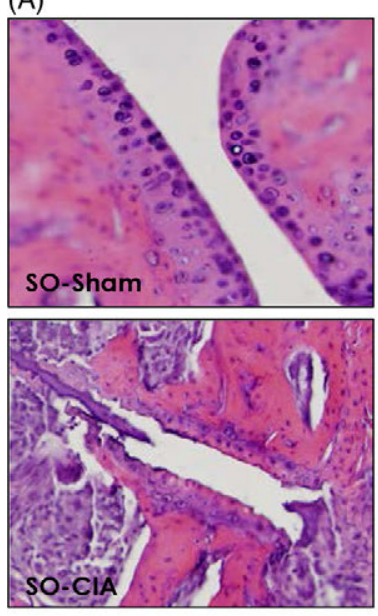
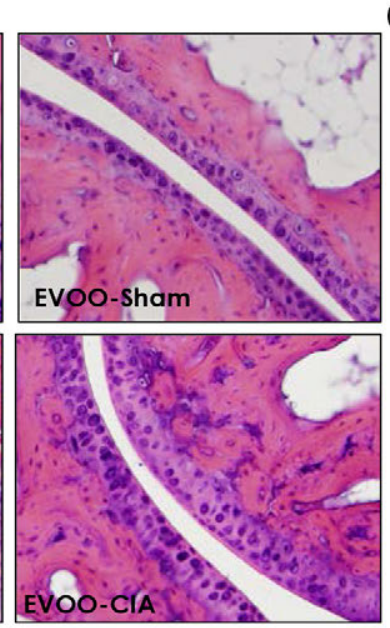

(B)
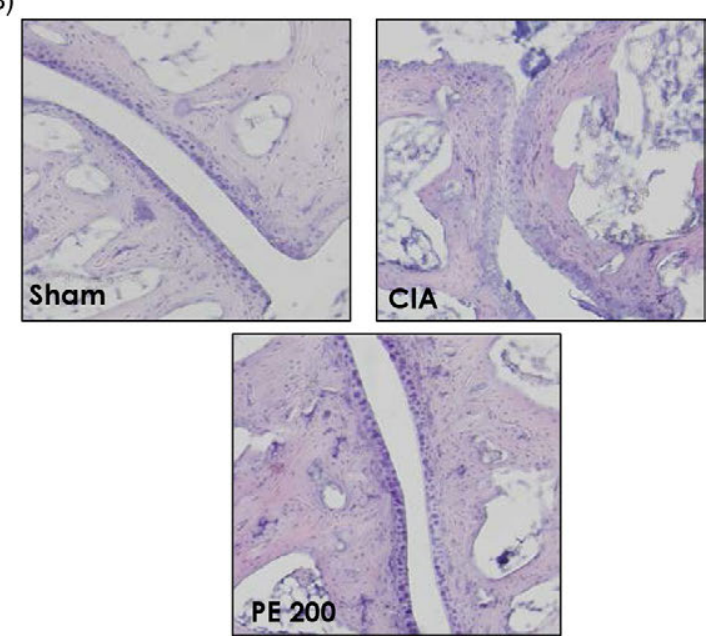

FIGURE 2. Histological analysis of the frontal sections of knee joints on day 42. Sections were stained with H\&E. Original magnification x200. (A) Dietary EVOO treatment: SO-Sham, non-arthritic mice fed with SO diet; EVOO-Sham, non-arthritic mice fed with EVOO diet; SO-CIA, control arthritic group fed with SO diet; EVOO-CIA, arthritic mice fed with EVOO diet. (B) PE treatment: Sham, non-arthritic mice; CIA, control arthritic group; PE 200, arthritic mice treated with PE (200mg/kg/day p.o. from

days 29 to 41 after immunization. The images are representative of at least six experiments performed on different days. 
(A)
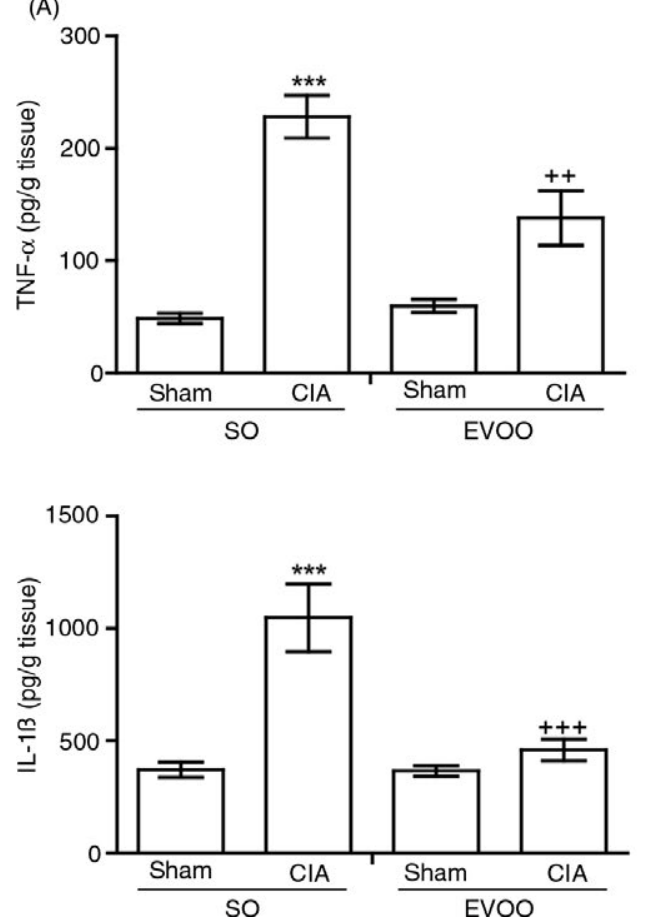

(B)
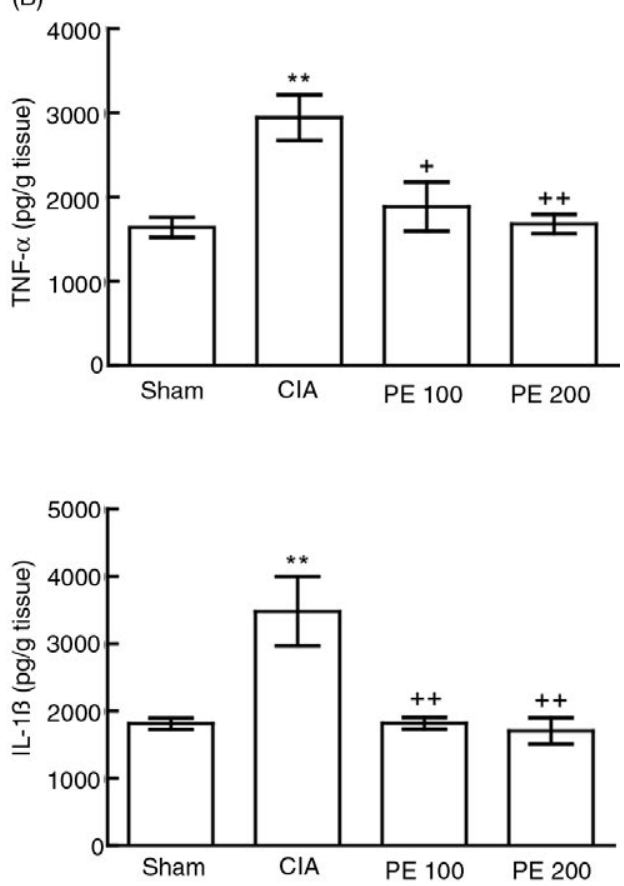

FIGURE 3. Measurement of TNF- $\alpha$ and IL- $1 \beta$ levels in hind paw homogenates. These were determined by ELISA kits. (A) Dietary EVOO treatment: SO-Sham, non-arthritic mice fed with SO diet; EVOO-Sham, non-arthritic mice fed with EVOO diet; SO-CIA, control arthritic group fed with SO diet; EVOO-CIA, arthritic mice fed with EVOO diet. (B) PE treatment: Sham, non-arthritic mice; CIA, control arthritic group; PE 100, arthritic mice treated with PE (100 mg/kg/day p.o. from days 29 to 41 after immunization); PE 200 , arthritic mice treated with PE $(200 \mathrm{mg} / \mathrm{kg} /$ day p.o. from days 29 to 41 after immunization. Data represent mean \pm S.E.M., $n=10$. $* * p<0.01$ and $* * * p<0.001$ vs. Sham; $+p<0.05,++p<0.01$ and $+++p<0.001$ vs. CIA.

(A)

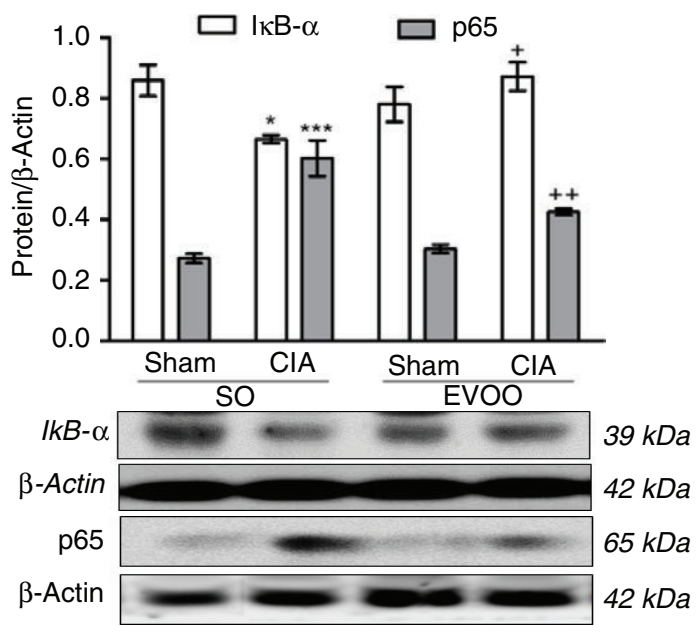

(B)

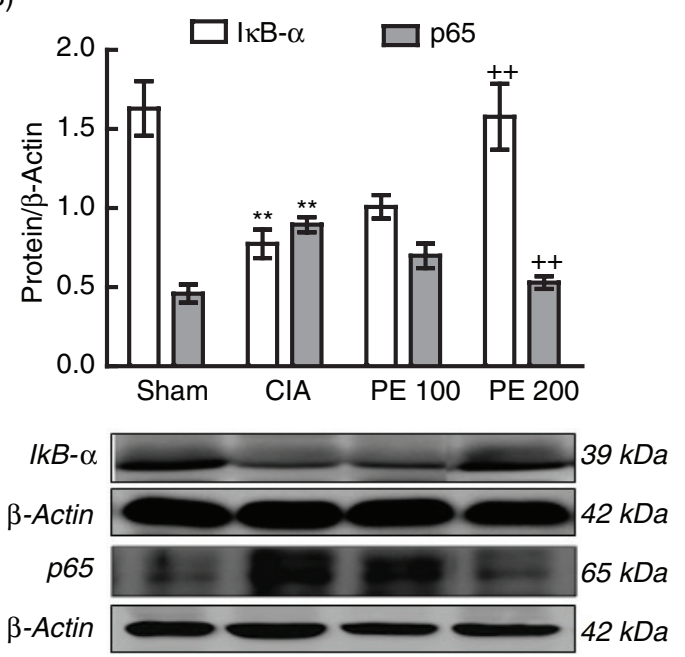

FIGURE 4. Expression of I $\mathrm{BB}-\alpha$ in cytoplasmic fraction and $\mathrm{p} 65 \mathrm{NF}-\kappa \mathrm{B}$ in nuclear fraction of homogenates from hind paws. (A) Dietary EVOO treatment: SO-Sham, non-arthritic mice fed with SO diet; EVOO-Sham, non-arthritic mice fed with EVOO diet; SO-CIA, control arthritic group fed with SO diet; EVOO-CIA, arthritic mice fed with EVOO diet. (B) PE treatment: Sham, nonarthritic mice; CIA, control arthritic group; PE 100, arthritic mice treated with PE ( $100 \mathrm{mg} / \mathrm{kg} /$ day p.o. from days 29 to 41 after immunization); PE 200, arthritic mice treated with PE (200mg/kg/day p.o. from days 29 to 41 after immunization. The expression was quantified by densitometry and normalized with respect to $\beta$-actin. Data represent mean \pm S.E.M., $n=4 .{ }^{*} p<0.05,{ }^{* *} p<0.01$ and $* * * p<0.001$ vs. Sham; $+p<0.05$ and $++p<0.01$ vs. CIA 
(A)

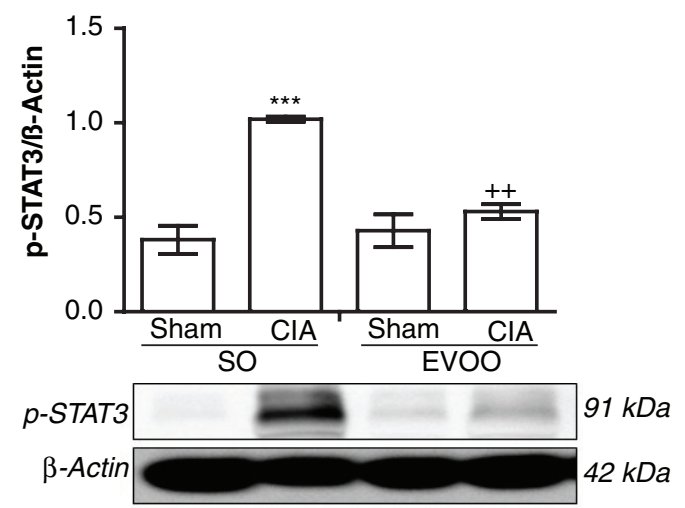

(B)

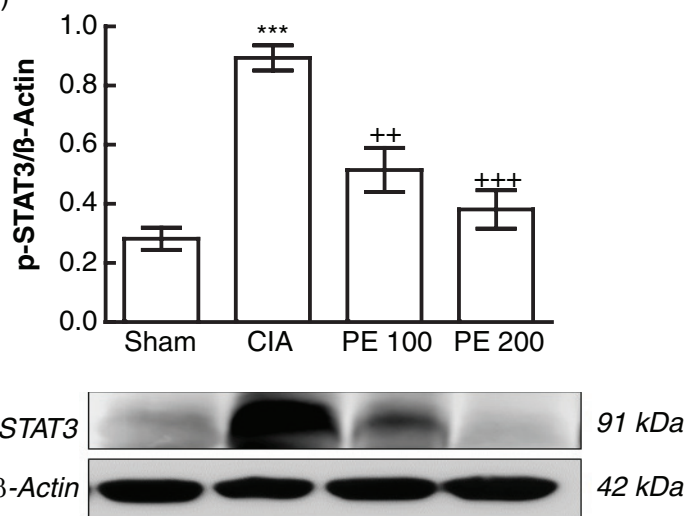

FIGURE 5. Changes in p-STAT3 protein expression in hind paw homogenates. (A) Dietary EVOO treatment: SO-Sham, non-arthritic mice fed with SO diet; EVOO-Sham, non-arthritic mice fed with EVOO diet; SO-CIA, control arthritic group fed with SO diet; EVOO-

CIA, arthritic mice fed with EVOO diet. (B) PE treatment: Sham, non-arthritic mice; CIA, control arthritic group; PE 100, arthritic mice treated with PE (100 mg/kg/day p.o. from days 29 to 41 after immunization); PE 200, arthritic mice treated with PE (200mg/kg/day p.o. from days 29 to 41 after immunization. The expression of p-STAT3 was quantified by densitometry and normalized with respect to $\beta$-actin. Data represent mean \pm S.E.M., $n=4$. ${ }^{* * *} p<0.001$ vs. Sham; $++p<0.01$ and $+++p<0.001$ vs. CIA.

(A)
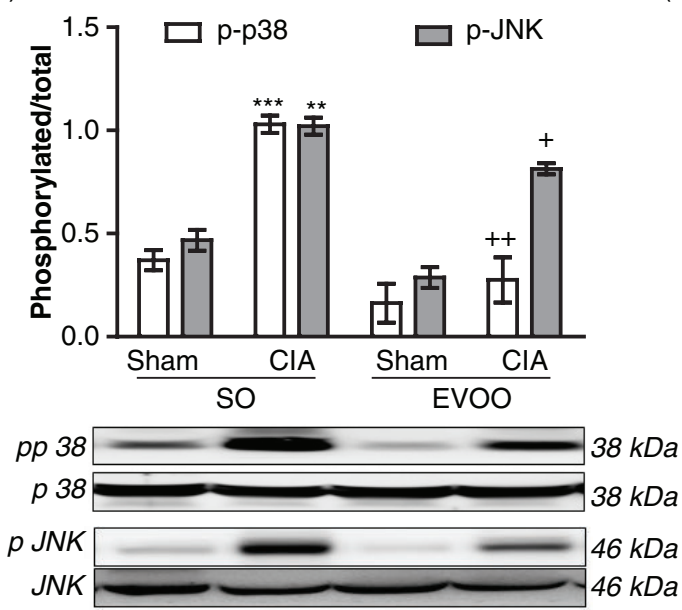

(B)
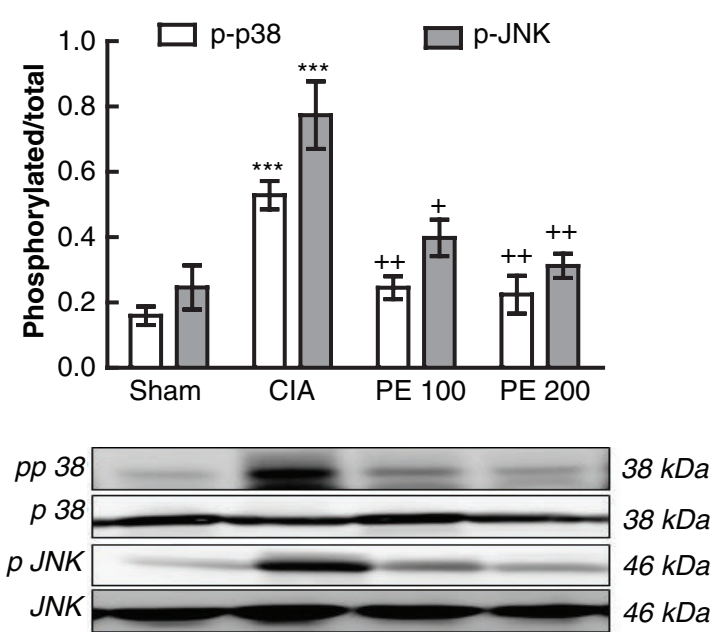

FIGURE 6. Effect of dietary EVOO on JNK and p38 MAPKs phosphorylation in hind paw homogenates. (A) Dietary EVOO treatment: SO-Sham, non-arthritic mice fed with SO diet; EVOO-Sham, non-arthritic mice fed with EVOO diet; SO-CIA, control arthritic group fed with SO diet; EVOO-CIA, arthritic mice fed with EVOO diet. (B) PE treatment: Sham, non-arthritic mice; CIA, control arthritic group; PE 100, arthritic mice treated with PE (100 mg/kg/day p.o. from days 29 to 41 after immunization); PE 200, arthritic mice treated with PE ( $200 \mathrm{mg} / \mathrm{kg}$ /day p.o. from days 29 to 41 after immunization. The expression of phosphorylated proteins was expressed related to the expression of the corresponding total protein. Data represent mean \pm S.E.M., $n=4 .{ }^{* *} p<0.01$ and $* * * p<0.001$ vs. Sham; $+p<0.05,++p<0.01$ vs. CIA.

considered as supportive nutritional therapy for RA patients and its polyphenolic fraction may provide an attractive nutraceutical complement in the management of RA, mainly when the effects of inexpensive, side effect-free therapies based on dietary EVOO might suppose an improvement in public health and the prevention of chronic pathologies with high prevalence in the population.

\section{ACKNOWLEDGMENTS}

This study was supported by research Grants AGL 2011-26949 (Ministerio de Economía y Competitividad, ISCIII, FEDER) and P-10AGR-6609 (Junta de Andalucía). The authors gratefully acknowledge the assistance of Center for Technology and Innovation Research, University 
of Seville (CITIUS). The authors wish to thank the $\mathrm{I}+\mathrm{D}+\mathrm{i}$ de Oleoestepa $\mathrm{SAC}$ department for providing the EVOO.

\section{REFERENCES}

Aaronson DS, Horvath CM. 2002. A road map for those who don't know JAK-STAT. Science 296, 1653-1655. http:// dx.doi.org/10.1126/science. 1071545

Alarcón de la Lastra C, Barranco MD, Motilva V, Herrerias JM. 2001. Mediterranean diet and health: biological importance of olive oil. Curr Pharm Des. 7, 933-950. http:// dx.doi.org/10.2174/1381612013397654

Bermúdez B, López S, Ortega A, Varela LM, Pacheco YM, Abia R, Muriana FJ. 2011. Oleic acid in olive oil: from a metabolic framework toward a clinical perspective. Curr. Pharm. Des. 17, 831-843. http://dx.doi. org/10.2174/138161211795428957

Cárdeno A, Sánchez-Hidalgo M, Alarcón-de-la-Lastra C. 2013. An up-date of olive oil phenols in inflammation and cancer: molecular mechanisms and clinical implications. Curr. Med. Chem. 20, 4758-4776. http://dx.doi.org/10.2174/0929 8673113209990159

Carrillo C, Cavia M, Alonso-Torre S. 2012. Role of oleic acid in immune system; mechanism of action; a review. Nutr Hosp. 27, 978-990.

Gong D, Geng C, Jiang L, Cao J, Yoshimura H, Zhong L. 2009. Effects of hydroxytyrosol-20 on carrageenan-induced acute inflammation and hyperalgesia in rats. Phytother Res. 23, 646-650. http://dx.doi.org/10.1002/ptr.2686

Han Z, Boyle DL, Chang L, Bennett B, Karin M, Yang L, Manning AM, Firestein GS. 2001. c-Jun N-terminal kinase is required for metalloproteinase expression and joint destruction in inflammatory arthritis. J. Clin. Invest. 108, 73-81. http://dx.doi.org/10.1172/JCI12466

Impellizzeri D, Esposito E, Mazzon E, Paterniti I, Di Paola R, Morittu VM, Procopio A, Britti D, Cuzzocrea S. 2011. Oleuropein aglycone, an olive oil compound, ameliorates development of arthritis caused by injection of collagen type II in mice. J. Pharmacol. Exp. Ther. 339, 859-869. http://dx.doi.org/10.1124/jpet.111.182808

Jeong JG, Kim JM, Cho H, Hahn W, Yu SS, Kim S. 2004. Effects of IL-1beta on gene expression in human rheumatoid synovial fibroblasts. Biochem. Biophys. Res. Commun. 324, 3-7. http://dx.doi.org/10.1016/j.bbrc.2004.09.011

Martínez-Domínguez E, de la Puerta R, Ruiz-Gutiérrez V. 2001. Protective effects upon experimental inflammation models of a polyphenol-supplemented virgin olive oil diet. Inflamm. Res. 50, 102-106. http://dx.doi.org/10.1007/ s000110050731

Morel J, Berenbaum F. 2004. Signal transduction pathways: new targets for treating rheumatoid arthritis. Joint Bone Spine 71, 503-510. http://dx.doi.org/10.1016/j.jbspin. 2004.03.004

Okamoto H, Yoshio T, Kaneko H, Yamanaka H. 2010. Inhibition of NF-kappaB signaling by fasudil as a potential therapeutic strategy for rheumatoid arthritis. Arthritis Rheum. 62, 82-92. http://dx.doi.org/10.1002/art.25063

Omar SH. 2010. Oleuropein in olive and its pharmacological effects. Sci. Pharm. 78, 133-154. http://dx.doi.org/10.3797/ scipharm.0912-18

Puertollano MA, Puertollano E, Álvarez de Cienfuegos G, de Pablo Martínez MA. 2010. Olive oil, immune system and infection. Nutr. Hosp. 25, 1-8.

Rudan I, Sidhu S, Papana A, Meng SJ, Xin-Wei Y, Wang W, Campbell-Page RM, Demaio AR, Nair H, Sridhar D, Theodoratou E, Dowman B, Adeloye D, Majeed A, Car J, Campbell H, Wang W, Chan KY. 2015. Prevalence of rheumatoid arthritis in low- and middle-income countries: A systematic review and analysis. J. Glob. Health 5, 010409 .

Salgado E, Maneiro JR. 2014. New therapies for rheumatoid arthritis. Med. Clin. (Barc) 143, 461-466. http://dx.doi. org/10.1016/j.medcli.2013.11.011

Smedslund G, Byfuglien MG, Olsen SU, Hagen KB. 2010. Effectiveness and safety of dietary interventions for rheumatoid arthritis: a systematic review of randomized controlled trials. J. Am. Diet Assoc. 110, 727-735. http:// dx.doi.org/10.1016/j.jada.2010.02.010

Suzuki M, Tetsuka T, Yoshida S, Watanabe N, Kobayashi M, Matsui N, Okamoto T. 2000. The role of p38 mitogenactivated protein kinase in IL-6 and IL-8 production from the TNF-alpha- or IL-1beta-stimulated rheumatoid synovial fibroblasts. FEBS Lett. 465, 23-27. http://dx.doi. org/10.1016/S0014-5793(99)01717-2

Vázquez-Roncero A, Janer del Valle M, Janer del Valle L. 1976. Determinación de los polifenoles totales del aceite de oliva. Grasas Aceites 24, 350-357. 